\title{
最近の歯学
}

\section{4. 無機材料}

\section{細胞接着活性なバイオコンポジットスキャホールド}

\section{東京医科歯科大学生体材料工学研究所 素材部門 無機材料分野} 木付貴司, 大柿真毅, 中村 聡, 山下仁大

これまで, ヒトの血漿と無機イオン濃度を等しくした擬似 体液を用いた新規生体材料の生体活性試験や骨類似アパタイ トをコーティングする技術（バイオミメティック）が開発さ れてきた。HAp 焼結体は, 細胞培養液に浸漬した場合, 擬似 体液浸漬により析出する骨類似アパタイトに酷似したバイオ コンポジットスキャホールド $(\mathrm{BcS})$ を形成する1)。細胞培養 時には, この BcS 形成と細胞成長が同時に進行するが, 本研 究では BcS を形成させた後に細胞培養を行うことで, BcS 上での細胞挙動を調査した ${ }^{2,3)}$ 。

通常, 細胞培養実験には, 最小必須培地に血清を $10 \%$ 程度 添加した培養液を用いる。培養液中での層形成には, 試料に 対する添加した血清成分の吸着が大きく影響する。培養液に 浸漬した直後から HAp 焼結体表面に血清タンパクの吸着が 起こり, アパタイトの核形成を阻害する。本研究では, 血清 タンパクの影響を考慮し, 滅菌処理した HAp 焼結体を無血 清培地 $(\alpha-\mathrm{MEM})$ と血清添加培地 $(\alpha-\mathrm{MEM}+10 \% \mathrm{FBS})$ の それぞれに浸漬した。その結果, 無血清培地浸漬に比べ, 血 清添加培地浸漬では層形成が抑制された。また, 走査型電子 顕微鏡 $(\mathrm{SEM})$ 観察より, 無血清培地中からの形成層は網目 状, 血清添加培地中で形成された $\mathrm{BcS}$ は球状粒子の集合し た膜状であった。

これら形成層上での細胞挙動を調査するため, 骨芽様細胞 株（MC 3 T 3-E 1）を用いた細胞培養実験を行った。培地浸 漬の後, 所定の濃度に調整した細胞浮遊液を滴下し, 一定期 間静置培養した。培養後, 接着細胞数の計数, およびに SEM による形態観察を行った。

無血清培地からの形成層上では, 通常の HAp セラミック ス上に比べ接着細胞数が減少し, 血清添加培地からの BcS 上では増加した（図 1)。また無血清培地からの形成層上での 接着細胞は, 球形あるいは擬足突起を伸ばした紡鍾状で接着 面積が小さく, SEM 観察の前処理段階で剝離するものも あった。一方, $\mathrm{BcS}$ 上の細胞は紡錘状あるいは偏平状であり, 浸漬期間の増加, つまり $\mathrm{BcS}$ 形成量の増加に伴い偏平状の 細胞が多くなり，BcSに密着することがわかった（図 2)。

培地に血清を添加した場合，骨類似アパタイト形成とタン パク吸着が同時進行する。これにより，血清タンパクを含む $\mathrm{BcS}$ が形成される。骨芽様細胞は比較的貪食作用が強く, 接 着した状態で $\mathrm{BcS}$ を侵食する。このとき, 層内部にも血清夕 ンパクを含んでいることで, 侵食を繰り返しても細胞と基質 との間に介在する接着タンパクが存在しており, 細胞が密着 すると考えられる。以上より, 血清タンパク吸着と骨類似ア パタイト形成の同時進行により得られる $\mathrm{BcS}$ は, 細胞の接 着を強化しうる表面状態であることを明らかにした。この細 胞接着活性な $\mathrm{BcS}$ 形成技術は, 擬似体液中で骨類似アパ夕 イトを形成するさまざまな材料にも応用可能であると考えら れる。

\section{文献}

1) Ohgaki, M., Katsura, M., Kizuki, T. and Yamashita,
K. : Electrovectorial effect of crystal formation and cell proliferation on polarized ceramics. Trans. Mater. Res. Soc. Japan 25 (1) : 169-172, 2000.

2) Kizuki, T., Ohgaki, M., Katsura, M., Hashimoto, K., Toda, Y., Udagawa, S. and Yamashita, K. : Modulation of adherence of osteoblast-like cells by electrical polarization of hydroxyapatite ceramics. Bioceramics $13: 333-336,2000$

3) Kizuki, T., Ohgaki, M., Katsura, M., Nakamura, S., Hashimoto, K., Toda, Y., Udagawa, S. and Yamashita, K. : Effect of bone-like layer growth from culture medium on adherence of osteoblast-like cells. Biomaterials. (In press)

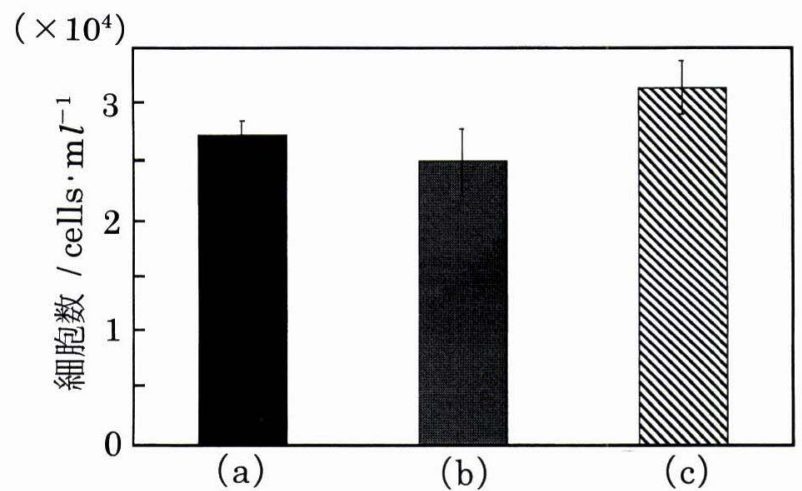

図 1 培養 3 日後における各種材料表面上の接着細胞数

(a) HAp セラミックス

(b) 骨類似アパタイト層（無血清培地）

(c) バイオコンポジットスキャホールド（血清添加培地）

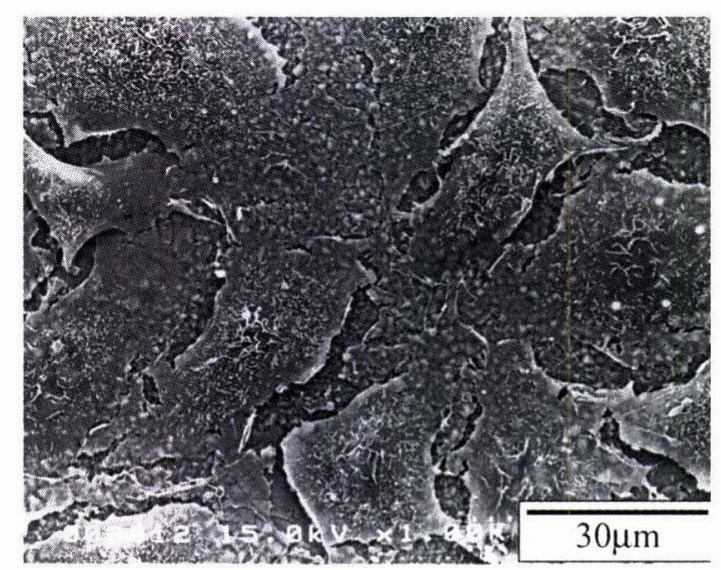

図 2 バイオコンポジットスキャホールド上に密着した骨芽 様細胞 